\title{
Factors Affecting Revenue Growth by County Governments in Kenya
}

\author{
Kimani Antony Macharia ${ }^{1}$, Dr. Oluoch Oluoch $^{2}$, Dr. Margaret Ncabira ${ }^{3}$ \\ ${ }^{1,2,3}$ School of business, Jomo Kenyatta University of agriculture and technology, Kenya
}

\begin{abstract}
The study sought to identify factors affecting revenue growth among County Governments in Kenya using Kiambu County as the case study. County Government of Kiambu consistently failed to meet its revenue collection targets following the creation of devolved governments after the promulgation of the new Constitution of Kenya 2010. County Governments were expected to collect own-source revenues to supplement equitable, conditional and unconditional grants received from the National Government. Its specific objectives included to establish the effect of public participation on revenue growth, to establish the effect of technology on revenue growth, to establish the effect of enforcement of laws on revenue growth, and to establish the effect of increase of taxation on revenue growth. The research employed a descriptive survey research design. Primary data was collected using questionnaires, while secondary data was derived from published material regarding devolution and revenue collection by sub-national governments in Kenya and beyond. The Statistical Package for Social Sciences and Microsoft Excel were used to analyse and process the primary data collected, and the information generated was presented in form of tables. All the factors affecting revenue growth (public participation, technology, enforcement of laws, and increase of taxation) were found to be significant using a multiple linear regression as shown by their positive beta coefficients of ( $\beta=0.935)$ with $P$ Value $<0.05$ at .000 , $(\beta=0.867)$ with $P$ Value $<0.05$ at $.000,(B=0.825)$ with $P$ Value $<0.05$ at .000 , and $(B=0.725)$ with $P$ Value $<0.05$ at .000 respectively. These findings affirmed the importance of the factors under study and therefore County Governments should put due consideration for optimum revenue growth.
\end{abstract}

KEYWORDS: Revenue growth, Public participation, Increase of taxation, Technology, Enforcement of laws

\section{INTRODUCTION}

On 23rd April 2018, the 5th Devolution Conference in Kenya opened its doors to the participants in Kakamega County. Among the participants were both the County and National Government officials. The conference theme was 'Sustainable, productive, effective and efficient governments for results delivery'. In 2019, the theme of the 6th Devolution conference held in Kirinyaga County changed to 'Deliver. Transform. Measure.' However, beneath the pomp and colour of the events lay the grim reality that although the Kenya Constitution 2010 has expressly provided for local sources of revenue for County Governments, nevertheless, they have always relied on equitable share of revenue from national sources because they have not put in place effective and efficient policies, laws and strategies for local revenue mobilization. This may undermine the envisaged sustainable, productive, effective and efficient governments for results delivery. Consequently, they may not deliver and transform as expected. Own source revenue is important to the County Governments as it enables them to meet their development needs and provide services to the people efficiently. This study seeks to identify the factors that affect revenue growth in County Governments with a view to recommending strategies to mitigate the problem.

\section{GENERAL OBJECTIVE}

The general objective of the study was to determine factors affecting revenue growth by the County Governments in Kenya relying on the case study of Kiambu County.

\section{Specific Objectives}

The specific objectives of the study were;

(i)To establish the effect of public participation on revenue growth

(ii) To find out the effects of technology on revenue growth

(iii) To determine the effect of enforcement of laws on revenue growth.

(iv) To examine the effect of increase of taxation on revenue growth.

\section{THEORETICAL PERSPECTIVES}

Theory of public participation

This is a public policy theory on public participation. The theory was described by David Ricci in 1971 (Luton, 1996). Group theory rests on the contention that interaction and struggle among groups are the central facts of political life. Group theory assumes the following is true for public policymaking: Most demands and supports for policy are manifest through organized groups; No single group can monopolize power. The most influential group will be decided by the amount of competition and the qualities of the 
competing groups; Policy results from compromise; Political actors are objective referees who state which group won. However, this theory overstates the importance of groups and ignores the role that public officials play in policymaking. Some policies are made by judges (with no dominant group winning), and the President has great influence over what policy areas are given attention. Additionally, not all interests are represented by groups and a few groups do monopolize the influence over some policy areas (for example, the American Medical Association in USA or the Kenya Bankers Association in Kenya)

\section{The Theory of Optimal Taxation}

Tax is a compulsory levy made by public authorities for which nothing is received directly in return (James and Nobes, 2012/2013). Taxes are, therefore, transfers of money to the public sector but they exclude loan transactions and direct payments for publicly produced goods and services.

The tax structure is part of economic organization of a society and therefore fit in its overall economic environment. The primary aim of the tax should be to raise revenue for public services. People should be asked to pay according to their ability to pay and assessment of their taxable capacity should be made primarily on the basis of income and property. Tax should not be discriminatory in any aspect between individuals and also between various groups.

\section{Rational Expectations Theory of Technology}

According to Au and Kauffman (2005), many information technology (IT) adoption decisions depend on the firm's expectations about the costs and benefits of the technology. It is based on rational expectations hypothesis (REH) and adaptive learning theory. REH postulates that people form their expectations based on the 'true' structural model of the economy on which their decisions are made. The basic assumption of the theory is that people use all the information available to them efficiently (Muth, 1961). However, Sargent (1993) suggested the theory of adaptive learning to relax REH's strong assumptions. In this theory, people learn about the economic circumstances and update their expectations about relevant parameter values on the basis of the newlyreceived information.

\section{Theory of Public Enforcement of Law}

Public enforcement of law is the use of agents of government to detect and to sanction violators of legal rules. These include, inter alia, the police, prosecutors and regulators. Four basic questions are essential to this theory. They include sanctions-fine or imprisonment or a combination of both; Rule-strict or liability based; whether sanction can be adjusted; and how much of the society's resources should be used in apprehending violators of the rules (Levitt and Miles, 2007).

\section{EMPIRICAL REVIEW LITERATURE Public Participation}

Decision making around government revenues and expenditures in the past was faced with secrecy, in most cases the treasury, central bank officials, the tax administrator were the only bodies responsible for decisions regarding public spending. Parliament interference with public finances was prohibited. However, with devolved government, interest and action with regard to public participation and accountability in fiscal decision-making has increased (Omwami \& Omwami, 2010).

Past studies on this topic indicate that the need for public participation has been attributed to the several factors. Firstly, there is the introduction of good governance practices and standards that ensure that there is transparency, participation and accountability in all matters of the government. Secondly, abolishing authoritarian political regimes and introducing open power systems, separation of powers and party competition. Thirdly, the introduction of modern public finance management systems and good practices around the world has stirred the need for public participation (Omwami \& Omwami, 2010). In addition, devolution, which in effect has led to decentralization of power and authority to raise, allocate and spend public resources, has resulted to increased transparency.

Public participation in planning, budgeting and oversight at both the national and county levels of government in Kenya is guaranteed by the constitution and the Public Finance Management (PFM) Act. Sec 35(1) and Sec 125 of PFM Act 2012 elaborately outline the stages in the budget process at the national and county government levels respectively in any financial year.

A study by Mudaki \& Masaviru (2012) found that citizens may not effectively participate in decision making due to a number of reasons. First, public finance is perceived to be technical and complex; it's only the treasury that can influence public finance decisions. Secondly, low capacity, and awareness on their rights implies that citizen spaces are vulnerable to capture by the elite and other groups with varied interests thus crowding-out the "genuine" public from participating. In a study on revenue management in County Governments, Odhiambo et al (2020) recommended the engendering of public participation in County Governments as a key pre-requisite for promotion of revenue growth.

The chapter entails presentation of research methodology that was adopted in the current study. Specifically, the chapter focuses on presentation of research design, targeted audience and instrument of data collection, data analysis as well as presentation.

\section{Increase of Taxation}

Taxes are an important source of revenue required for proper functioning and provision of services by both national and county governments. This is especially so in the context of 
huge development requirements in most of the counties in the face of inadequate resources from the National Treasury (Kinuthia, 2010). However, the manner in which such taxes are raised must not only be done in accordance with the law but also exercised responsibly. Art 209 of the Constitution provides that taxation and other revenue raising measures of a County shall not be exercised in a way that prejudices national economic policies (CoK, 2010).

In the recent past, the country has witnessed sporadic conflicts between the County Governments and the business community following introduction of new taxes and charges. In some counties, this has been marked by disruptive riots and protests as witnessed in Mombasa, Kiambu, Nairobi, Nyeri, Machakos and Meru.

Nearly every empirical study of taxes and economic growth published in a peer reviewed academic journal finds that tax increases harm economic growth. The Government of Kenya has recently raised taxes in order to increase its revenue and finance various development projects. Although an increase in taxes increases the revenue stream to the government, it also has implications for economic growth, since, while an increase in government revenue and hence expenditure may increase income, a raise in taxes could have disincentives in the economy that more than counter the intended increase in economic growth from government expenditure While focusing on revenue growth, governments must also be careful to balance this with economic growth (Kilonzo, 2012).

\section{Use of Technology}

ICT infrastructure is a key foundation necessary for the success of domestic resources foundations and its pillars. It seeks to provide the integrated infrastructure backbone required to enable cost effective delivery of ICT products and services such as revenue collection for counties, businesses and other stakeholders. The fact that ICT has a critical role in driving the economic, social and political development of Kenya as espoused in Vision2030 cannot be gainsaid. It is a roadmap to a knowledge-based economy and society that will lead to real socio-economic and revenue growth (Shrum et al, 2011).

A study carried out by the CRA in conjunction with USAID through AHADI program in 2017 on County Governments' revenue automation systems with a view to assessing automation impact and gaps discovered weaknesses in the revenue management systems. They included partial automation of revenue streams, multiple independent revenue management systems, weak internal control, inconsistent cash and bank reconciliations, inadequate staffing and technical capacity of staff and ownership of data by vendors (Odhiambo et al, 2020).

\section{Enforcement}

Uneven tax administration in Africa is a major contribution to revenue shortfalls that augment inflationary pressure while depriving governments' resources with which to provide public goods. Uneven tax administration also stimulates resort to more easily collected taxes on foreign trade with associated efficiency loss.

Ali et al, (2014) revealed that theoretical and empirical research on why persons subject to tax comply or fail to comply with their legal liabilities has been pursued by social scientists from various disciplines. The findings indicate that the direct benefit of successful tax evasion is obvious, it is the value of the payments evaded, comprising their resources thereby saved. Drawing from 'reference group theory' he attributes tax evasion to a norm neutralization process i.e. tax evaders justifying their cheating by the belief that everyone else does the same thing. There is also the belief that the benefit the tax evader receives from government fall below his/her share of the tax burden (Kariuki, 2012).

\section{RESEARCH METHODOLOGY}

\subsection{Introduction}

Research methodology deals with the description of the methods applied in carrying out the research study. It provides for the procedures to be followed in conducting the study (Kombo \& Tromp, 2006). This helps other researchers in understanding one's study, particularly where replication may be desired.

It is organized under the following sections; research design, population, sampling techniques, research instruments, data collection procedures and data analysis.

\subsection{Research Design}

This study employed a descriptive survey research design. Descriptive survey design was used to allow the researcher gather information, summarize, present and interpret for purpose of clarification. The major purpose of survey research design is description of the state of affairs as it exists at present (Kothari, 2011). The choice of the description survey research design was made based on the fact that in the study, the researcher was interested in the state of affairs already existing in the field and no variable was manipulated. Descriptive research design was chosen because it is flexible. That is, it allows the researcher to generalize the findings where a large population is involved

\subsection{Empirical Modeling}

Multiple linear regression using SPSS was then applied to analyze Factors Affecting Revenue Collection by the County Government of Kiambu. The following model was applied:

$$
\begin{gathered}
\mathbf{Y}=\boldsymbol{\beta 0}+\boldsymbol{\beta 1 X 1}+\boldsymbol{\beta 2 X 2}+\boldsymbol{\beta 3 X 3}+\boldsymbol{\beta 4 X 4}+\boldsymbol{\varepsilon} \\
\ldots \ldots \ldots \ldots \ldots \ldots \ldots \ldots \ldots \ldots \ldots \ldots \ldots \ldots \ldots \ldots \ldots \ldots \\
\text { Equation } 3.1
\end{gathered}
$$

Where,

$\mathrm{Y}=$ Revenue collection efficiency (optimal revenue collection)

$\beta 0=$ Constant or coefficient of intercept

$\mathrm{X} 1$ = Public Participation

$\mathrm{X} 2$ = Increased taxation 
$\mathrm{X} 3=$ Technology

$\mathrm{X} 4$ = Enforcement of laws

$\beta 1 \ldots \beta 4=$ Represents the corresponding coefficients for the respective independent variables

$\varepsilon=$ Error term i.e. disturbance factors which represents residual or values that are not captured within the regression model.

The overall significance of the model was tested using analysis of variance by use of $F$ statistics at $95 \%$ confidence level while the coefficient determination R2 was used to show the contribution of independent variables on the dependent variable.

The model was first subjected to F-test to establish whether the variables were jointly significant. T-tests were further computed for the individual variables' coefficients to determine their significance in the model. Null hypothesis was accepted or rejected based on the p-value obtained. The decision rule was to reject the hypothesis where $\mathrm{p}$ value $=$ $<0.05$.

\subsection{Target Population}

According to Kothari (2011) population refers to a group of people that have one thing in common. Target population is defined as all members of a real or hypothetical set of people, events or objects to which a study wishes to generalize the results of the research study (Mackey \& Gass, 2013).

The target population for the study were the policy makers of the Kiambu County Government who include the Kiambu County Executive members and the Kiambu County Assembly members (In this study the focus was on the members of the Finance, Budget and Appropriations Committee. This is because the committee is the one responsible for oversight on finance and budget issues hence more relevant to the study). The study also interviewed a list of registered businesses in the County through structured questionnaires assisted by research assistants and adopted a representative sample to collect the data from the Single Business Permit holders in Kiambu County.

\subsection{Data Collection Instruments}

A questionnaire was designed and administered to assess the factors affecting revenue growth in the County Government of Kiambu. The target population were the policy makers of the Kiambu County Government who include the Kiambu County Executive Members and the Kiambu County Assembly members (In this study the focus was on the members of the Finance, Budget and Appropriations Committee. This is because the committee is the one responsible for oversight on finance and budget issues hence more relevant to the study).

The study also interviewed a list of registered businesses in the county through structured questionnaires assisted by research assistants and adopted a representative sample to collect the data from the Single Business Permit holders in Kiambu County. The study sample size was four hundred and three (403). This included three hundred and eighty-four (384) registered businesses with single business permits operating in Kiambu county, and nineteen (19) policy makers from Kiambu County Government.

\subsection{Data Analysis and Presentation}

According to Gast \& Ledford (2009), data analysis is bringing order, structure and meaning to the information collected. The primary data collected from the field was first cleaned in order to get the response rate. This implied that any questionnaires that were insufficiently filled were deemed to be unsuitable for the next phase of data processing and analysis. The data was coded prior to entering into the computer. The Statistical Package for Social Sciences (SPSS) tool was used in data processing and analysing.

\subsubsection{Reliability Tests}

Reliability measures the degree to which a research instrument yields consistentF results or data after repeated trials (Cronbach, 1971). A statistical coefficient - Cronbach's alpha $(\alpha)$ was used as a measure of internal reliability. It was used to measure the internal reliability of the questionnaire. Reliability coefficient of 0.7 or more indicates high reliability of the data (Mugenda, 2011). Cronbach's alpha reliability coefficient ranges from 0 and 1 . Reliability coefficient of 0 implies that there is no internal reliability while 1 indicates perfect internal reliability. The optimal value of 0.7 was used as a cut-off of dependability. Therefore, a high degree of reliability of the data was reflected in the study results as shown below;

\section{Table 4.1: Reliability Coefficients}

\begin{tabular}{lll} 
Cronbach Alpha $(\alpha)$ & \multicolumn{2}{c}{ No of Items } \\
Public Participation & 0.779 & 11 \\
Increase of Taxation & 0.811 & 8 \\
Use of Technology & 0.822 & 5 \\
Enforcement & 0.866 & 7 \\
Reliability*** & 0.898 & 31
\end{tabular}

\subsubsection{Response Rate}

A total of 403 questionnaires were administered on the sampled respondents. Out of this number 300 were successfully filled and picked from the respondents. This translates to $74.4 \%$ response rate. This was sufficient and satisfactory for analysis. Nulty (2008) asserts that $70 \%$ response rate is the threshold. Therefore, the study response rate had surpassed the threshold.

\section{Descriptive Statistics}

This section illustrates descriptive findings and discussions relative to the research goals. The findings are presented in means and standard deviation as measures of central tendency and variation respectively. 


\section{Summary Statistics on Public Participation and Revenue Growth}

The researcher conducted summary statistics for public participation using mean and standard deviation on a five point Likert scale where strongly agree (5.0000-4.500), agree (4.499-3.500), neutral (3.4999-2.500), disagree (2.499-1.500) and strongly disagree (1.499-1.000)

The study findings revealed that on the question of access to information, the respondents from the Budget and Appropriation committee agreed with a mean of 3.6000 that the business operators in the county received information on the taxes, tariffs, fees and charges proposed for implementation and their input on the same is sought. The members of the County Executive Committee strongly agreed with a mean of 4.5000 on this position. However, the business community disagreed with the policy makers on this issue with a mean of 2.1000 . This implied that business community does not get information on the proposed taxes, fees and charges for their feedback and only learn about the same during implementation.

On the issue of consultation, the Budget and Appropriation Committee was neutral with a mean of 3.1500 on whether adequate consultation is conducted with the stakeholders in the business sector. The County Executive Committee members agreed with a mean of 3.9500 that adequate consultations were conducted with the business community on revenue raising measures proposed by the county government. The holders of the Single Business Permit disagreed with a mean of 1.9200 on this position. This was an indication that there is no effective consultation between the business community and the county government on proposed taxes, fees and charges among other policies implemented by the county government.

Regarding the question of active participation, the Budget and Appropriations Committee agreed with a mean of 3.7200 that the business community alongside other members of the public actively participated in public fora organized to discuss the revenue raising measures proposed by the county government. This position was supported by the County Executive Committee Members who agreed with a mean of 4.0000. However, the holders of Single

Business Permits strongly disagreed with a mean of 1.3520 on the position that there is active participation of the business community in financial policies of the county. This implied that there is little or no structured and deliberate involvement of the business community in active participation during discussions to discuss the revenue raising measures of the county government. Hence the county government introduces permits, fees and charges without adequate input from the business community with rates being unreasonably high.

On the question of a legislative framework to guide public participation in the county, the members of the Budget and Appropriations Committee strongly disagreed with a mean of 1.2000 on the existence of a legislative framework. They indicated that they were in the process of developing one in consultation with the senate which had provided a model bill on public participation. The County Executive Committee Members supported that position and disagreed with a mean of 1.5860 on the existence of a legislative framework. However, the Single Business Permit holders were neutral on the issue with a mean of 2.6100 and didn't know whether such a law on public participation exists or not.

The findings on public participation are in agreement with the position of Bishop (2012) who asserts that to have influence and to be able to help shape governmental decisions, a group must have access, or the opportunity to express its viewpoints to decision-makers. Mudaki \& Masaviru (2012) states that, citizens may not effectively participate in decision making due to a number of reasons. First, public finance is perceived to be technical and complex; it's only the treasury that can influence public finance decisions. Secondly, low capacity, and awareness on their rights implies that citizen spaces are vulnerable to capture by the elite and other groups with varied interests thus crowdingout the "genuine" public from participating.

Nonetheless, it is imperative to note that public participation is one of the national values and principles provided by Kenya Constitution 2010 and the County Governments have no choice but to conduct the same. Previous experience has demonstrated that residents may indeed resort to court action and seek stay of the implementation of any taxes, fees and charges or indeed any policy that they were not involved in developing e.g. the case of Republic v County Government of Kiambu Ex parte Robert Gakuru \& Another [2016] eKLR where the court stopped the implementation of the Finance Act on account of lack of public participation.

Hence the need to conduct effective public participation following the stages of access to information, consultation and active involvement. When such public participation is real, deliberate and not illusory or a formality, policies geared towards revenue growth among others are likely to be embraced by the community and hence implemented with ease.

Summary statistics on technology and revenue growth

On the question of availability of modern ICT infrastructure at the County Government of Kiambu, the Members of the Budget \& Appropriation Committee agreed with a mean of 3.6120. The County Executive Committee members strongly agreed on this position with a mean of 4.6120. However, the holders of Single Business Permit were neutral on that question with a mean of 2.6000 .

Regarding use of mobile \& electronic platforms in revenue collection, the members of the Budget \& Appropriations Committee agreed with a mean of 3.6100. The County Executive Committee members strongly agreed with a mean of 4.6250 on the use of the ICT platforms to collect revenue. However, the business community disagreed on the use of the 
ICT platforms to collect revenue with a mean of 2.4610. This was an indication that the use of the gadgets was yet to be fully employed in certain areas. Some traders were still being asked to pay cash. It was therefore necessary for the county government to ensure that the gadgets were working at all times and if possible investigate the reasons why they were not operational in some areas. This will ensure that all money collected reached the county government coffers.

On the question as to whether the use of ICT tools will enhance efficiency and effectiveness in revenue collection and management, the Budget \& Appropriation Committee strongly agreed with a mean of 4.7200. The County Executive Committee strongly agreed as well with a mean of 4.7500 . The Single Permit holders agreed on the benefits of ICT tools use with a mean of 3.5120 . The use of ICT tools to collect revenue would curb corruption and ensure that all money collected reaches the accounts of the County Government and hence used to provide services to the public.

On the issue of ICT convenience and saving time for the rate payers, the Budget \& Appropriations Committee strongly agreed on that position with a mean of 4.5000. The same position was adopted by the County Executive Committee who strongly agreed with a mean of 4.6510. The Single Business Permit holders strongly agreed with a mean of 4.7510 that the effective use of the ICT tools to collect revenue such as the mobile and electronic payment platforms would be convenient to them and save time.

\section{Summary Statistics on Enforcement and revenue growth}

On the question of use of highly trained and skilled enforcement personnel, the Budget \& Appropriations Committee disagreed with a mean of 1.6200. The County Executive Committee agreed with a mean of 3.7210 . However, the business community represented by the Single Business Permit holders strongly disagreed with a mean of 1.3500. This implied that the enforcement team may have acted unprofessionally while dealing with the business community. Incidences of indiscipline and corruption are likely to occur when the enforcement personnel are not skilled, motivated and abuse the code of conduct. The team may consider giving the defaulters 'Notice to Appear in Court '(NTAC) instead of confiscating or destroying their wares and harassing them.

Regarding dispatch of reminder notices to the defaulters, the Budget \& Appropriations Committee disagreed with a mean of 1.6100. The County Executive Committee agreed with a mean of 3.8100 that the County Government sent reminder notices to defaulters. On their part, the Single Business Permit Holders strongly disagreed with a mean of 1.3620 that the County Government sent reminder notices to them when they defaulted. A polite reminder would enable traders to secure money to pay for their licences in good time and it would spare the government the resources it puts in the enforcement drive which can be utilised for service delivery. Hence a cordial relationship between the County Government and the business community would be mutually beneficial and would help in enhancing revenue collection.

On the question of strict enforcement of fines and penalties, the Budget \& Appropriations Committee disagreed with a mean of 2.3200. This is an indication that sometimes the fees are lost to corruption. On the other hand, the County Executive Committee strongly agreed on the strict enforcement of fines and penalties with a mean of 4.6500 . However, the Single Business Permit holders agreed with a mean of 3.6000 on the strict enforcement of fines and penalties on defaulters. This implies that while the SBP holders may have paid some money as sanctions for defaulting in meeting conditions for payment of business permit, such money may remain unaccounted for fuelling fears of corruption.

Regarding support from National Government enforcement agencies such as the police, the Budget \& Appropriations Committee was neutral with a mean of 2.6000. However, the County Executive Committee agreed with a mean of 3.6000. The holders of the Single Business Permit on their part strongly agreed with a mean of 4.5000 on the use of the police by the County Government during enforcement of payment against the defaulters. The findings of the study are in agreement with Ali et al (2014) in terms of tax evasion, tax rate and enforcement. He attributes tax evasion to a norm neutralization process i.e. tax evaders justifying their cheating by the belief that everyone else does the same thing. There is also the belief that the benefit the tax evader receives from government fall below his/her share of the tax burden. Hence with strict, lawful and professional enforcement process, coupled with good governance, effective and efficient service delivery, there is likely to be enhancement of revenue collection by the County Government.

\section{Summary statistics on increase of taxation and revenue growth}

About the increase of single business permit fees, the Budget \& Appropriations Committee agreed with a mean of 3.6500. However, the County Executive Committee disagreed with a mean of 1.8750 . The traders on the other hand strongly agreed with a mean of 4.5000 with the position that the County Government had increased the Single Business Permit fees. This implied that any efforts to rationalise taxes between the different sub-counties in the county based on their potential was perceived as increment of taxes. Increase of taxes by the County Government would hurt businesses besides undermining national macroeconomic stability and employment creation.

On the increase of other taxes, fees and charges, the Budget \& Appropriation Committee agreed with a mean of 3.5000 . However, the County Executive Committee disagreed with a mean of 2.0000 that they had increased other taxes, fees and charges. On their part, the traders strongly agreed with a mean 
of 4.6000 that the County Government had increased other taxes, fees and charges.

Regarding introduction of new taxes, fees and charges, the Budget \& Appropriations Committee agreed with a mean of 3.6000. This position was supported by the County Executive Committee which agreed with a mean of 3.5000. This implied that the County Government was keen on widening the tax bracket and reach those not paying instead of over-burdening the existing tax-payers. On their part, the traders agreed with a mean of 3.5000 that new taxes, fees and charges had been introduced.

The findings of the study are in tandem with the views of Kilonzo (2012). According to him, while focusing on revenue growth, governments must also be careful to balance this with economic growth. Governments, therefore, have to be able to draw a balance between raising revenue and the implications for this on economic growth.

\section{CONCLUSION}

The findings of the study demonstrate the need to consider public participation as an important factor in enhancing revenue growth and indeed any public policy decision taken by the county governments and other public bodies. It is not only a constitutional dictate but also significant in determining revenue growth. At the heart of an effective system of public financial management is the principle of democratic consent. The principle demands that taxation and spending should not be done without the explicit consent of the governed.

When people are informed, consulted and actively involved in revenue management, they are likely to embrace measures that are geared towards revenue enhancement to secure more effective and quality service delivery. However, where public participation is not seen as legitimate, it can alienate the public from the government and disrupt the implementation of policy decisions (Innes and Booher, 2004; Ozawa, 2012).

Another important consideration that has to be made is employing technology in revenue collection and management. Substantial investment has to be made in infrastructure outlay and also take advantage of mobile and electronic pay platforms to improve efficiency not only in revenue collection but also in service delivery. The requisite technical training and skills should be developed to support the technology. This will boost revenue growth and promote effective, efficient and transparent revenue management and service delivery.

\section{REFERENCES}

1. Aaron H.J, \& Boskin M.J, (1980). The Economics of Taxation. Washington DC. Brooking Institution.

2. Achrol, R. S., \& Kotler, P. (2012). Frontiers of the Marketing Paradigm in the Third Millennium.
Journal of the Academy of Marketing Science, 40(1), 35-52.

3. Adam Smith International (2020). The Revenue Potential: How Kenya's County Governments could close their Financing Gaps.

4. Agénor, P. R., \& Neanidis, K. C. (2011). The Allocation of Public Expenditure and Economic Growth. The Manchester School, 79(4), 899-931.

5. Alene, A. D. (2010). Productivity Growth and the Effects of $R \& D$ in African Agriculture. Agricultural Economics, 41(3-4), 223-238.

6. Ali, M., Fjeldstad, O. H., \& Sjursen, I. H. (2014). To Pay or Not to Pay? Citizens' Attitudes Toward Taxation in Kenya, Tanzania, Uganda, and South Africa. World Development, 64, 828-842.

7. Allingham, M.G., \& Sandmo, A. (1972). Income Tax Evasion: A theoretical Analysis. Journal of Public Economics, 1, 323-338.

8. Au, Y. A., \& Kauffman, R. J. (2005). A Rational Expectations Theory of Technology Adoption: Evidence from the Electronic Billing Industry. Workshop on Information Systems. https://doi.org/10.1080/0960310042000176371 Au, Y. A., \& Kauffman, R. J. (2005).

9. Au, Y. a, \& Kauffman, R. J. (2003). What do you know? Rational Expectations in Information Technology Adoption and Investment. Journal of Management Information Systems, 20(2), 49-76.

10. Balunywa et al (2014). An Analysis of Fiscal Decentralisation as a Strategy for Improving Revenue Performance in Ugandan Local Governments. Journal of Research in International Business and Management, 4 (2), 2251-28. https://doi.org/10.14303/jribm.2013.011

11. Baumgartner, F. R., Jones, B. D., \& Mortensen, P. B. (2014). Punctuated Equilibrium Theory: Explaining Stability and Change in Public Policymaking. Theories of the policy process, 59103.

12. Baunsgaard, T., \& Keen, M. (2010). Tax Revenue and (or?) Trade Liberalization. Journal of Public Economics, 94(9), 563-577.

13. Bird, R.M. (2004). Administrative Dimensions of Tax Reform. Asia-Pacific Bulletin, 10,134-150.

14. Bird, R.M. (2010). Taxation and Development. Poverty Reduction and Economic Management Network. World Bank Report.

15. Bishop, D. M. (2012). Group Theory and Chemistry. Courier Corporation.

16. Brautigam, D. (2004). The People's Budget? Politics, Participation and Pro-Poor Policy. Development Policy Review, 22 
17. Brondolo, J. (2008). Tax Administration Reform and Fiscal Adjustment: Institute of certified public accountants of Kenya.

18. Bryson, J. et al (2013). 'Designing Public Participation Processes', Public Administration Review, 73 (1), 23-34

19. Burugu, J. (2010). The County. Centre for Leadership Education and Development (CLEAD) International

20. Çağman, N., Çıtak, F., \& Aktaş, H. (2012). Soft IntGroup and its Applications to Group Theory. Neural Computing and Applications, 21(1), 151-158.

21. Chitembo, A. (2009). Fiscal Decentralisation: A Comparative Perspective. Civil Society Representatives Sitting on the Zambian National Constitutional Conference (NCC). Lusaka.

22. Clist, P., \& Morrissey, O. (2011). Aid and Tax Revenue: Signs of a Positive Effect Since the 1980s. Journal of International Development, 23(2), 165180.

23. CIC, (2014). 50 Things Every Kenyan Needs to Know About Public Finance Under The Constitution. International Budget Partnership (IBP).

24. CoB (2015). Annual County Budget Implementation Review Report 2013/2014. Controller of Budget. Nairobi. Government Printer

25. CoK (2010). The Constitution of Kenya. Nairobi. Government Printer.

26. Corey, G. (2011). Theory and Practice of Group Counselling. Cengage Learning

27. CPST (2015). The Constitution, Parliament and Governance Systems: A Manual of the Centre for Parliamentary Studies and Training. Smart Printers. Nairobi

28. Cronbach, L. (1971). Test Validation. In R. Thorndike (Ed.), Educational Measurement (2nd ed., p.443). Washington DC: American Council of Education.

29. Dallal, L. (2012). The Psychology of Organizations. John Wiley. USA

30. Davis, F. (1989). Perceived Usefulness, Perceived Use of Ease, and User Acceptance of Information Technology. MIS Quarterly, Miniapolis (MN), v.13, n.3, p.319-339

31. Devas, D., \& Hubbard, D. (2001). The Composition of Public Expenditure and Economic Growth. Journal of Monetary Economics.

32. Devas, N., \& Roy, K. (2001). Regulation or Revenues? An Analysis of Local Business Licences, with a Case Study of the Single Business Permit Reform in Kenya. John Wiley \& Sons Ltd.

33. Edgeworth, F. (1958). The Pure Theory of Taxation. In Musgrave R.A., Peacock A.T. (eds) Classics in the Theory of Public Finance. International Economic Association. Palgrave Macmillan, London

34. Eggers, W.D (2005). E-Government. Oxford. Rowman and Littlefield Publishers.

35. Fjeldstad, O. H., \& Heggstad, E. R. (2012). New Challenges for Local Government Revenue Enhancement.

36. Fjeldstad, O. (2009). New Challenges for Local Government Revenue Enhancement in Tanzania.

37. Frankema, E. (2011). Colonial Taxation and Government Spending in British Africa, 1880 1940: Maximizing Revenue or Minimizing Effort? Explorations in Economic History, 48(1), 136-149.

38. Gidisu, T. E. (2012). Automation System Procedure of the Ghana Revenue Authority on the Effectiveness of Revenue Collection: A Case Study of Customs Division, Unpublished MBA Thesis, Kwame Nkrumah University of Science and Technology.

39. Guba, E.G, \& Lincoln, Y.S. (1989). Fourth Generation Evaluation. Sage Publications.

40. Heap, K. (2014). Group Theory for Social Workers. Elsevier.

41. James, S. \& Nobes, C. (1997) The Economics of Taxation: Principles, Policy and Practice. Prentice Hall.

42. James, S. \& Nobes, C. (2012/2013) The Economics of Taxation: Principles, Policy and Practice. Prentice Hall.

43. Joseph, R.C (2009). A Theoretical Framework for Egovernment in Developing and Emerging Economies. Harrisburg. Pennsylvania State University.

44. ICPAK, 2014. Public Finance Building Blocks for Devolution: A Baseline Survey on Devolution in Kenya with Respect to Public Financial Management Systems. www.icpak.com

45. Innes, J. \& Booher, D. (2004). 'Reframing Public Participation: Strategies for the 21st Century', Planning, Theory and Practice, 5 (4), 419-436, London: Routledge.

46. International Monetary Fund (2008). Finance and Development. A Quarterly Magazine of the IMF, Vol 45, No 4

47. Kariuki, D. (2009). A Study on Systematic Change Management at Kenya Revenue Authority. Unpublished MBA Project, University of Nairobi.

48. Kariuki, E. (2012). Performance Measurement in African Semi-Autonomous Revenue Authorities: The Case of Kenya, South Africa and Tanzania (Doctoral dissertation, PhD-thesis, University of Bradford). 
49. Kayaga, L. (2007). Tax Policy Challenges Facing Developing Countries: A Case Study of Uganda. A Master's Thesis Submitted to Queen's University Kingston, Ontario, Canada.

50. Kelly, R. \& Devas, N. (2001). Regulation or Revenue? An Analysis of Local Business Licences, with a Case Study of the Single Business Permit in Kenya. www.researchgate.net

51. Kilonzo, T. M. (2012). The Effects of Tax Amnesty on Revenue Growth in Kenya (Doctoral dissertation).

52. Kim, J. \& Lau, L. (1994). The Sources of Economic Growth of the East Asian Newly Industrialized Countries. Journal of the Japanese and International Economies 8,235-271

53. Kombo, D. K, \& Trump, D.L.A, (2006). Proposal and Thesis Writing: An Introduction. Nairobi. Paulines Publications Africa.

54. Kothari, C. R. (2011). Research Methodology: Methods and Techniques. New Age International.

55. Kuyoro, S., Awodele, O. \& Okolie, S. (2012). ICT: An Effective Tool in Human Development. International Journal of Humanities and Social Science Vol 2 No 7.

56. Latema, M. (2011). Business Models for Revenue Generation and Enhancement by County Governments in Kenya. University of Nairobi.

57. Levitt, S. \& Miles, T. (2007). 'Empirical Study of Criminal Punishment' In: Polinsky, A.M., Shavell, S. (Eds.), Handbook of Law and Economics, vol. 1. North-Holland, Amsterdam. 